\title{
PEMBELAJARAN MICROTEACHING SELAMA MASSA COVID-19 BERBASISKANTUGAS PROYEKBAGI MAHASISWA PENDIDIKAN KIMIA
}

\section{Nyoman Tika ${ }^{1^{*}}$, Siti Maryam²}

1,2 Jurusan Kimia , Universitas Pendidikan Ganesha, Singaraja, Indonesia

*Corresponding Author: tika90@gmail.com

\section{A R T I C L E I N F O}

Article history:

Received August 12, 2021

Revised August 20, 2021

Accepted October 02, 2021

Available online October 25, 2021

Kata Kunci:

Microteaching,

Pembelajaran berbasis

proyek

Keywords:

Microteaching, project

based learning.

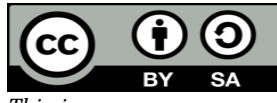

This is an open access article under the CC BY-SA license.

Copyright (C) 2021 by Author. Published by Universitas

Pendidikan Ganesha.

\begin{abstract}
A B S T R A K
Matakuliah microteaching merupakan salah satu mata kuliah yang menekankan pada kegiatan praktek mengajar, hanya saja dengan adanya kebijakan pembelajaran jarak jauh pelaksanaan praktek tidak dapat berlangsung dengan maksimal.Tujuan penelitian ini adalah untuk mendeskripsikan keterampilan mengajar mahasiswa calon guru Kimia saat pandemic COVID-19 melalui pemberian tugas berbasis proyek. Jenis penelitian ini adalah pra-eksperimental dengan desain One Group Pretest dan Posttest. Subjek penelitian ini adalah 8 orang mahasiswa yang mengikuti perkuliahan Pengajaran Mikro. Pengumpulan data dalam penelitian dilakukan dengan menggunakan metode observasi, wawancara dan angket.Instrumen yang digunakan adalah lembar penilaian video mengajar mahasiswa. Keterampilan dasar mengajar dinilai atas 8 komponen yaitumembuka pelajaran, mengelola kelas, memberikan penguatan, bertanya, menjelaskan pelajaran, penggunaan media pembelajaran, mengadakan variasi, dan menutup pelajaran. Skor penilaian setiap komponen menggunakan skala 5 Hasil penelitian menunjukkan bahwa nilai rata-rata keterampilan mengajar mahasiswa pada saat pre-test sebesar 61 sedangkan pada saat posttest sebesar 89.38. Nilai komponen keterampilan mengajar saat pretest yang terendah adalah keterampilan mengelola kelas, sedangkan yang tertinggi adalahketerampilan membuka pelajaran. Dengan demikian, pemberian tugas berbasis proyek meningkatkan keterampilan mengajar mahasiswa calon guru kimia saat pandemic COVID-19 sebesar 28,38 poin, dengan komponen keterampilan mengajar yang paling tinggi adalah penggunaan membuka pelajaran dengan nilai Gain sebesar 85 . Sehingga dapat ditarik kesimpulan bahwa penggunaan model pembelajaran berbasis pryek secara signifikan mampu melatih keterampilan dasar mengajar calon guru kimia, dengan kriteria tinggi.
\end{abstract}

\section{A B S T R A C T}

The microteaching course is one of the courses that emphasizes practical teaching activities, however, with the distance learning policy, practical implementation cannot take place optimally. The purpose of this study was to describe the teaching skills of prospective chemistry teacher students during the COVID-19 pandemic through project-based assignments. This type of research is pre-experimental with One Group Pretest and Posttest designs. The subjects of this study were 8 students who took part in Micro Teaching lectures. Data collection in the study was carried out using the methods of observation, interviews and questionnaires. The instrument used is a student teaching video assessment sheet. Basic teaching skills are assessed on 8 components, namely opening lessons, managing classes, providing reinforcement, asking questions, explaining lessons, using learning media, conducting variations, and closing lessons. The score for each component uses a scale of 5 . The results showed that the average value of students' teaching skills at the pre-test was 61 while at the posttest it was 89.38. The value of the teaching skills component at the pretest was the lowest in class management skills, while the highest was in opening lessons. Thus, giving project-based assignments improves the teaching skills of prospective chemistry teacher students during the COVID-19 pandemic by 28.38 points, with the highest component of teaching skills being the use of opening lessons with a Gain value of 85. So it can be concluded that the use of learning models project-based significantly able to train the basic skills of teaching chemistry teacher candidates, with high criteria. 


\section{PENDAHULUAN}

Pandemi covid-19 yang menyerang seluruh Negara di dunia termasuk Indonesia telah memberikan dampak yang signifikan terhadap seluruh aspek kehidupan manusia termasuk pada aspek pendidikan. Pada bidang pendidikan covid-19 telah membawa dimensi baru, kususnya dalam hal aspek penyelenggaraan pendidikan (Asmuni, 2020). Upaya yang dilakukan pemerintah untuk menekan penyebaran virus covid-19 dalam bidang pendidikan yakni dengan menerapkan kebijakan belajar dari rumah(Anugrahana, 2020; Astini, 2020; Oktawirawan, 2020). Kebijakan belajar dari rumah pada masa pandemi covid-19 harus dilaksanakan secara daring/dalam jaringan.Dalam pembelajaran daring kegiatan belajar mengajar yang umumnya dilaksanakan melalui proses tatap muka langsung antara guru dan siswa dialihkan menjadi proses tatap muka virtual dengan menggunakan berbagai aplikasi pendukung (Mansyur, 2020; Septyanti \& Kurniawan, 2020; Sobron et al., 2019). Kebijakan pelaksanaan pembelajaran daring diterapkan pada seluruh jenjang pendidikan termasuk pada jenjang perguruan tinggi (Walilu et al., 2021).

Pembelajaran daring pada jenjang perguruan tinggi dilaksanakan dengan memanfaatkan aplikasi pembelajaran daring yang telah disediakan oleh masing-masing perguruan tinggi (Cahyani et al., 2020). Pelaksanaan pembelajaran daring juga diterapkan pada seluruh mata kuliah termasuk pada mata kuliah microteaching. Mata kuliah microteaching merupakan mata kuliah yang dilaksanakan untuk dapat memberikan memberikan pengalaman mengajar yang nyata dengan memberikan sejumlah keterampilan mengajar sebelum mahasiswa terjun ke lapangan/sekolah (Hikmawati et al., 2020). Pengajaran Mikro merupakan praktik mengajar dalam lingkup kecil, dengan jumlah peserta berkisar antara 5 sampai 10 orang, ruang kelasnya terbatas, waktu pelaksanaannya berkisar antara 10 dan 15 menit, terfokus pada keterampilan mengajar tertentu, serta pokok bahasannya disederhanakan (Asril, 2017; Rachmadyanti, 2021). Dalam pembelajaran mikro mahasiswa sebagai calon guru dipersiapkan agar mampu menghadapi pekerjaan mengajar sepenuhnya di muka kelas dengan memiliki pengetahuan, keterampilan, kecakapan dan sikap sebagai guru yang profesional. Untuk melatih mahasiswa menjadi calon guru yang profesional dibutuhkan proses pembelajaran pengenalan lapangan, namun sebelumnya dilakukan pembelajaran mikro untuk melatih keterampilan dasar mengajar (Azrai et al., 2020). Pembelajaran mikro terbukti menjadi alat diagnostik yang efektif untuk mengidentifikasi kebutuhan spesifik mahasiswa calon guru dan alat persiapan untuk penempatan di kehidupan nyata atau sekolah nyata (Ledger \& Fischetti, 2020). Dalam proses pembelajaran mikro mahasiswa dikenalkan terhadap delapan keterampilan dasar mengajar yang terdiri dari keterampilan bertanya, keterampilan memberi penguatan, keterampilan mengadakan variasi, keterampilan menjelaskan, keterampilan membuka dan menutup pelajaran, keterampilan membimbing diskusi kelompok kecil, keterampilan mengelola kelas dan keterampilan mengajar kelompok kecil / perorangan (Nurwahidah, 2020; Rezania et al., 2020; Sufiati \& Afifah, 2019).

Hanya saja dengan adanya pandemic covid-19 proses perkualiahan microteaching tidak dapat berlangsung dengan maksimal. Kurang optimalnya proses pembelajaran pada mata kuliah mikro disebabkan karna mahasiswa tidak dapat melaksanakan prakter mengajar secara langsung. Dalam pandemi covid-19, kebijakan pemerintah dengan mengatur jarak (social distancing), maka pembelajaran microteaching tidak dapat dilakukan secara langsung, maka dilakukan secara daring.Sistem daring memiliki beberapa keterbatasan antara lainpembelajaran lebih banyak bersifat teoretis dan minim praktik karena tidak dimungkinkan adanya interaksi langsung dengan siswa, selain itu sulit untuk mengontrol mana siswa yang serius mengikuti pelajaran dan mana yang tidak (Asmuni, 2020; Napsawati, 2020). Oleh karena itu perkulihan microteaching yang membutuhkanpengelolaan kelas penggunaan media dan keterampilan dasar lainnya menjadi tidak dapat berlangsung dengan optimal. Kurang optimalnya proses perkuliahan microteaching kemudian berdampak pada kurangnya kemampuan mahasiswa dalam mengelola kelas serta kurangnya keterampilan siswa dalam proses belajar megajar. Untuk mengatasi permasalahan tersebut, maka dibutuhkan suatu inovasi pembelajaran yang mampu memaksimalkan proses perkuliahan microteaching. Salah satu upaya yang dapat dilakukan yakni dengan menerapkan model pembelajaran berbasis proyek.Model pembelajaran proyek merupakan salah satu upaya yang dapat dilakukan untuk melatih keterampilan mengajar mahasiswa calon guru pendidikan kimia. Pembelajaran berbasis proyek (PjBL) menjadi salah satu model pembelajaran yang tidak hanya membekali siswa dengan ilmu pengetahuan namun dalam proses pengerjaan proyek tersebut menuntut siswa untuk dapat mengimplementasikan pemahamannya dalam kehidupan nyata (Mulyaningsih et al., 2021; Rati et al., 2017). Model proyek merupakan metode pembelajaran yang menggunakan proyek/kegiatan sebagai media (Nirmayani \& Dewi, 2021). Peserta didik melakukan eksplorasi, penilaian, interpretasi, sintesis, dan informasi untuk menghasilkan berbagai bentuk hasil belajar (Fahrezi et al., 2020). Pembelajaran berbasis proyek berlandaskan pada teori belajar konstruktivis dengan menerapkan strategi belajar kolaboratif, serta mengutamakan aktivitas siswa daripada aktivitas pengajarnya (Karjiyati \& Agustdianita, 2017). Strategi instruksional untuk menghadirkan pembelajaran berbasis project based learning dapat diwujudkan 
melalui kegiatan laboratorium, pengalaman lapangan, studi kasus, pemecahan masalah, panel diskusi, diskusi, brainstorming, dan simulasi (Nurhikmayati \& Sunendar, 2020).

Beberapa penelitian yang telah dilakukan sebelumnya menyebutkan bahwa penerapan model Project Based Learning (PJBL) dalam pembelajaran fisika secara signifikan mampu meningkatkan kemampuan berpikir ktitis peserta didik (Anggreni, 2019). Penelitian lainnya juga mengungkapkan bahwa pembelajaran project based learning berpengaruh besar terhadap kemampuan pemahaman konsep mahasiswa prodi pendidikan matemtika, sehingga model tersebut sangat layak untuk digunakan (Wahyuni, 2019). Penelitian selanjutnya juga menyebutkan bahwa siswa termotivasi melaksanakan kerja proyek yang dilakukan, yang dikerjakan tanpa adanya beban dan membuahkan hasil yang maksimal, serta menjadi penilaian ujian praktik IPA di akhir belajar di sekolah (Handayani, 2020). Berdasarkan hal tersebut dapat dikatakan bahwa model pembelajaran berbasis proyek sangat layak digunakan dalam proses pembelajaran siswa maupun mahasiswa. Hanya saja pada penelitian sebelumnya belum terdapat kajian mengenai penggunaan model berbasis proyek dalam pembelajaran mata kuliah mikro di masa pandemic seperti saat ini.Sehingga penelitian ini difokuskan pada kajian tersebut dengan tujuan untuk mendeskripsikan keterampilan mengajar mahasiswa calon guru saat pandemic COVID-19 melalui pemberian tugas berbasis proyek.

\section{METODE}

Penelitian ini merupakan jenis penelitian pra-eksperimental dengan desain One Group Pretest dan Posttest. Subjek penelitian ini adalah mahasiswa yang mengikuti perkuliahan Pengajaran Mikro di Kelas D pada Program Studi Pendidikan Kimia, Universitas pendidikan Ganesha, semester genap tahun Pelajaran 2020/2021yang berjumlah8 orang. Pengumpulan data dalam penelitian dilakukan dengan menggunakan teknik observasi, wawancara dan angket.Dengan instrument penelitian berupa lembar penilaian video mengajar. Indicator lembar penilaian mengajar terdiri dari Audio visual (komposisi gambar dan cahaya), Substansi (kesesuaian video dan tema pengajaran), manfaat (edukatif dan memberikan nilai /value),serta jumlah like dan share.Keterampilan dasar mengajar yang dinilai terdiri atas 8 komponen yaitu membuka pelajaran, mengelola kelas, memberikan penguatan, bertanya, menjelaskan pelajaran, penggunaan media pembelajaran, mengadakan variasi, dan menutup pelajaran. Skor penilaian setiap komponen disajikan dalam skala 5. Analisis data hasil penelitian dilakukan dengan menggunakan rumus $\mathrm{N}$-gain yang kemudian dikonfersikan ke tabel tabel konfersi $\mathrm{N}$-gain.

\section{HASIL DAN PEMBAHASAN}

Hasil

Penelitian ini bertujuan untuk mendeskripsikan keterampilan mengajar mahasiswa calon guru Kimia saat pandemic COVID-19 melalui pemberian tugas berbasis proyek. Hasil penelitian tentang perbandingan skor keterampilan mengajar pada masing-masing komponen saat pretest dan posttest dapat dilihat pada Gambar 1. Komponen keterampilan mengajar pada Gambar 1 adalahmembuka pelajaran, mengelola kelas, memberikan penguatan, bertanya, menjelaskan pelajaran, penggunaan media pembelajaran, mengadakan varias, serta menutup pelajaran. Nilai komponen keterampilan mengajar yang terendah saat pretest adalah keterampilan menggunakan media, sebesar 57 (kriteria kurang baik), dan yang tertinggi adalah keterampilan mengadakan variasi sebesar 71 (kriteria cukup baik), sedangkan nilai komponen keterampilan mengajar yang terendah saat posttest adalah keterampilan menjelaskan pelajaran sebesar 79 (kriteria cukup baik) dan yang tertinggi adalah keterampilan memberikan penguatan dan menutup pelajaran sebesar 90 (kriteria sangat baik). Adapun hasil nilai rata-rata pretest dan posttest tiaptiap mahasiswa disajikan pada Gambar 2. Nilai rata-rata keterampilan mengajar mahasiswa pada saat pretest sebesar 67 (kriteria cukup baik) sedangkan pada saat posttest sebesar 86 (kriteria sangat baik). Dengan kata lain, terdapat peningkatan nilai keterampilan mengajar mahasiswa setelah pemberian tugas berbasis proyek berupa pembuatan video mengajar. Peningkatan nilai keterampilan mengajar mahasiswa per komponen dapat dilihat pada Tabel 3. Jadi, Nilai N-gain yang terendah adalah keterampilan mengelola kelas, yaitu sebesar 54 dengan kriteria sedang. Nilai $\mathrm{N}$-gain yang tertinggi adalah keterampilan membuka pembelajaran yaitu sebesar 85 , dengan kriteria tinggi. 


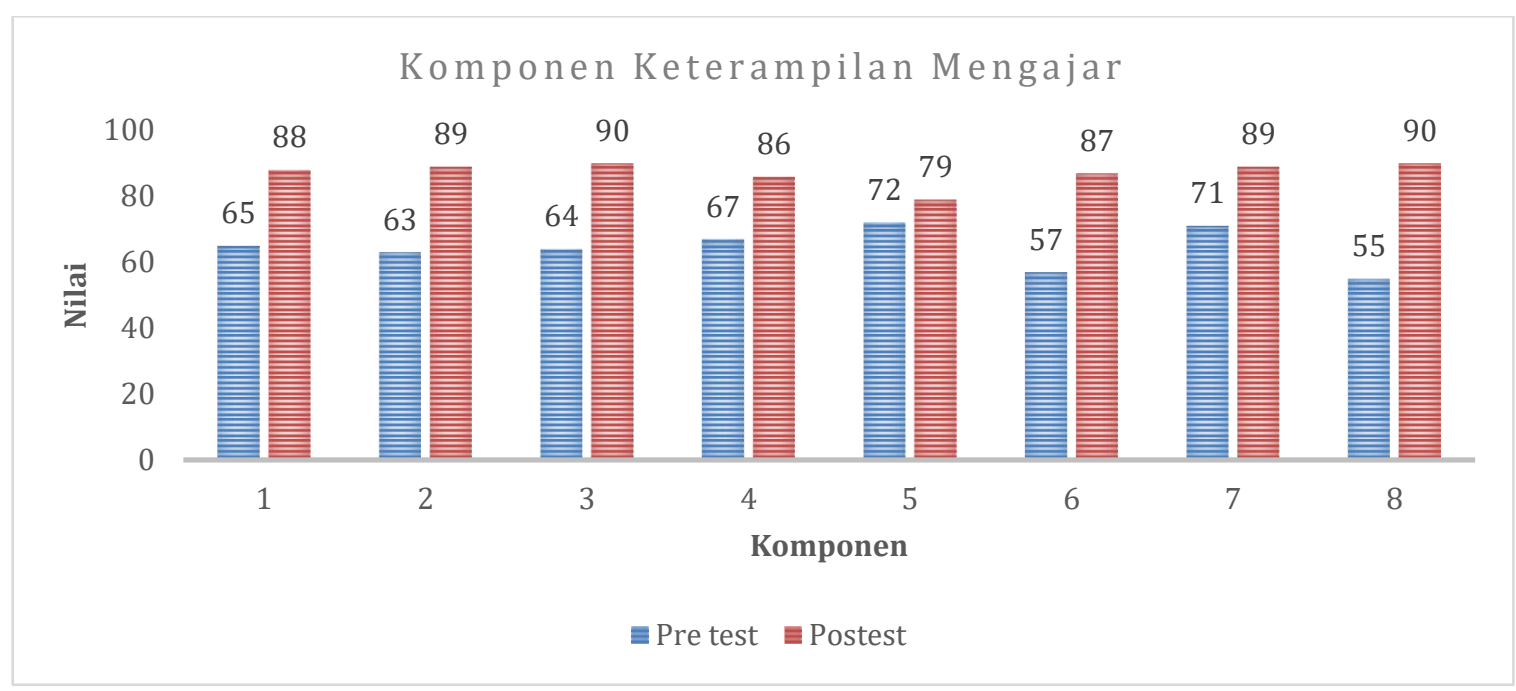

Gambar 1. Perbandingan Skor Keterampilan Mengajar Pada Masing-Masing Komponen

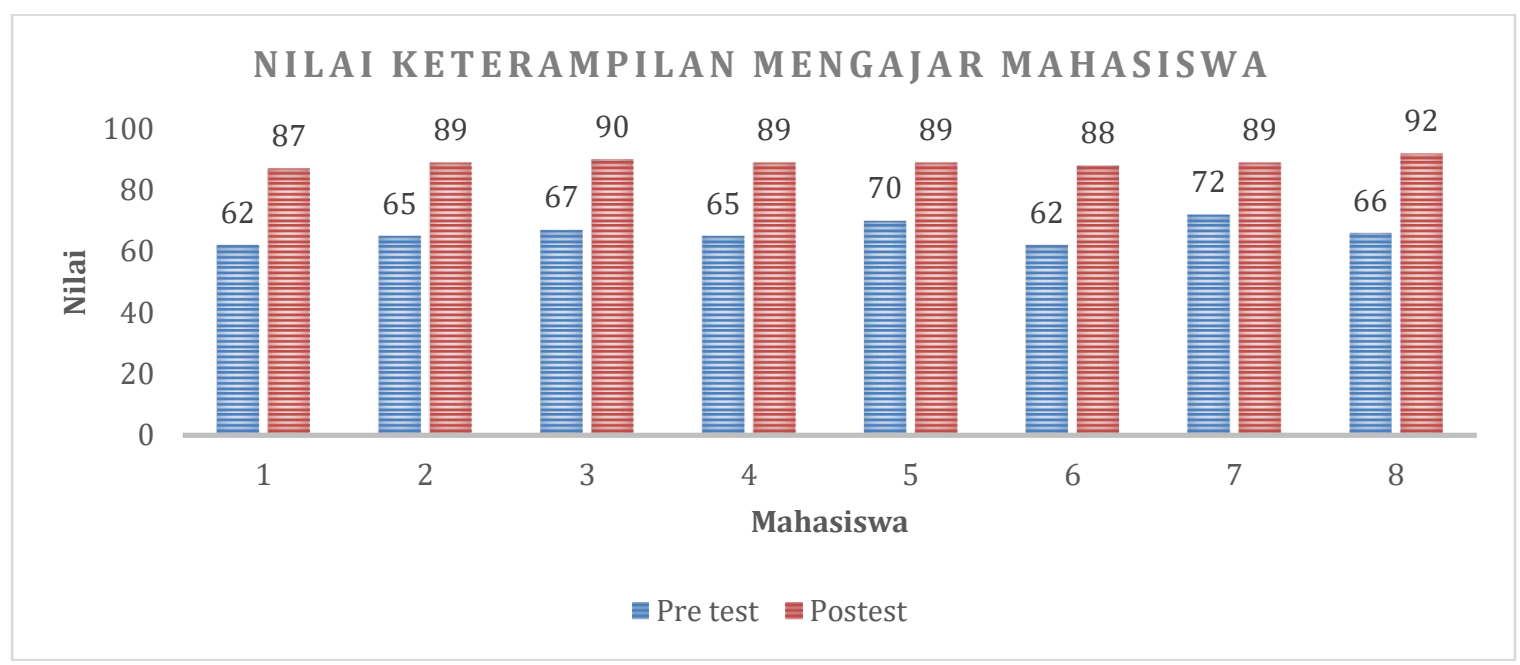

Gambar 2. Perbandingan Nilai pretest dan posttest keterampilan mengajar mahasiswa

Tabel 3. Peningkatan nilai keterampilan mengajar mahasiswa per komponen

\begin{tabular}{clcc}
\hline No & \multicolumn{1}{c}{ Komponen Keterampilan } & N-Gain & Kriteria \\
\hline 1 & Membuka pelajaran & 85 & tinggi \\
2 & Mengelola kelas & 54 & sedang \\
3 & Memberikan penguatan & 82 & tinggi \\
4 & Bertanya & 73 & tinggi \\
5 & Menjelaskan pelajaran & 75 & tinggi \\
6 & Penggunaan media pelajaran & 76 & tinggi \\
7 & Mengadakan variasi & 58 & sedang \\
8 & Menutup pelajaran & 80 & tinggi \\
\hline & Rata-rata & $\mathbf{7 3}$ & tinggi \\
\hline
\end{tabular}

\section{Pembahasan}

Hasil analisis penelitian menunjukkan bahwa terdapat peningkatan terhadap kemampuan mengajar mahasiswa setelah dibelajarkan dengan menggunakan model pembelajaran project based learning. Hasil yang diperoleh didasarkan pada penilaian pretest dan posttest.Nilai terendah saat pretest ditunjukkan pada keterampilan menggunakan media, sebesar 57 (kriteria kurang baik), dan yang tertinggi adalah keterampilan mengadakan variasi sebesar 71 (kriteria cukup baik), sedangkan nilai komponen keterampilan mengajar yang terendah saat posttest adalah keterampilan menjelaskan pelajaran sebesar 79 (kriteria cukup baik) dan yang tertinggi adalah keterampilan penguatan dan penutup pelajaran sebesar 90 (kriteria sangat baik). Hasil tersebut menegaskan bahwa kemampuan penguatan berkaitan dengan 
kemampuan guru untuk memberikan pengahargaan.Keterampilan memberikan penguatan atau reinforcement, secara garis besar dapat dimaknai sebagai kemampuan guru dalam memberikan respon terhadap perilaku siswa dalam kegiatan belajar mengajar, agar siswa terdorong untuk meningkatkan perilaku positif tersebut (Aini et al., 2019; Jeklin, 2019). Pada dasarnya istilah penghargaan, hadiah, pujian yang sering disama artikan dengan penguatan memiliki kedudukan sebagai bagian dalam keterampilan dalam memberi penguatan (Siahaan \& Meilani, 2019). Bagi mahasiswa pendidikan kimia dengan diberikan tugas membuat video menunjukkan kemampuan untuk memberikan penguatan. Pemberian penguatan oleh guru terhadap perilaku siswa akan mendorong siswa tersebut agar berbuat lebih baik lagi. Pemberian memberi penguatan atau reinforcement adalah suatu tindakan atau respons terhadap suatu bentuk perilaku yang dapat mendorong munculnya peningkatan kualitas tingkah laku tersebut di saat yang lain (Hikmawati et al., 2020). Hal ini tidak terlepas dari pengertian mengenai penguatan, dimana pengutan secara sederhana diartikan sebagai segala bentuk respons, apakah bersifat verbal ataupun nonverbal, yang merupakan bagian dari modifikasi tingkah laku guru terhadap tingkah laku siswa, yang bertujuan memberikan informasi atau umpan balik (feedback) bagi si penerima atas perbuatannya sebagai suatu dorongan atau koreksi (Sutisnawati, 2017).

Selanjutnya ditinjau dari aspek peningkatan kemampuan dasar mengajar yang bisa dilihat dari Nilai G score-nya, Keterampilan membuka pelajaran dalam video mengajar yang dibuat oleh mahasiswa pendidikan kimia dari 67 (kriteria sedang), menjadi 95 (kriteria tinggi), dengan nilai Gainnya, sebesar 85. Keterampilan mahasiswa dalam memberikan motivasi dan memusatkan perhatian pada saat membuka pelajaran, dapat mempengaruhi kemampuan mahasiswa, sehingga dapat dilihat dilihat hasil posttest sudah lebih baik daripada pretest. Hal ini dapat dijelaskan berdasarkan delapan aspek keterampilan mengajar siswa. Pada aspek keterampilan pertama, yakni keterampilan membuka pelajaran guru berupaya untuk menyiapkan peserta didik siap secara mental agar dapat menerima pelajaran, serta memusatkan perhatian siswa (Habibi \& Firmansyah, 2019; Sundari \& Muliyawati, 2017). Peran guru sejatinya, pada fase ini adalah memotivasi siswa agar peserta didik memiliki rasa ingin tahu (Ambarawati, 2016). Guru dapat meningkatkan rasa ingin tahu siswa. Pada titik ini, maka guru berperan sebagai inspirator.Oleh karena itu, mengajar adalah tindakan optimistis yang besar. Guru harus dapat membangun karakter optimis pada siswa, dan memusatkan perhatian, mengembangkan motivasi agar terpusat pada apa yang akan dipelajari (Irawati, 2020). Sehingga berdasarkan hal tersebut dapat diuraikan bahwa aspek yang dinilai dari keterampilan membuka pelajaran adalah menarik perhatian siswa, menggunakan alat bantu, pola interaksi yang bervariasi, memberikan motivasi, kehangatan, mengemukakan ide, memberikan acuan, mengingatkan kembali pelajaran lama dan menghubungkannya dengan pelajaran yang baru sesuai dengan Rencana Pelaksanaan Pembelajaran (Nurwahidah, 2020; Yuanita, 2019).

Pada aspek kedua yakni aspek pengelolaan kelas guru berupaya untuk menciptakan dan memelihara kondisi belajar yang optimal dan mengembalikannya bila terjadi gangguan dalam proses belajar mengajar (Aulia \& Sontani, 2018; Estiastuti \& Arini, 2017). Bila pengaturan kondisi dapat dikerjakan secara optimal, maka proses belajar berlangsung secara optimal pula. Aspek yang dinilai dari pengelolaan kelas adalah Penciptaan dan pemeliharaan kondisi belajar yang optimal (tempat duduk siswa, memulai pelajaran ketika siswa sudah siap) , Mengendalikan kondisi belajar yang optimal (penguatan , memodifikasi tingkah laku, mengelola kelompok). Kondisi pengelolaan yang baik dapat meningkatkan motivasi belajar siswa (Sumar, 2020). Aspek keterampilan yang ketiga yakni keterampilan memberikan penguatan yang dimaknai sebagai kemampuan guru dalam memberikan respon terhadap perilaku siswa dalam kegiatan belajar mengajar, agar siswa terdorong untuk meningkatkan perilaku positif tersebut (Ambarawati, 2016; Irawati, 2020). Keterampilan memberikan penguatan dapat dikelompokkan menjadi 2 jenis yaitu penguatan verbal (berupa kata-kata atau kalimat), dan penguatan non verbal (berupa mimik dan gerakan tubuh)(Habibi \& Firmansyah, 2019; Sundari \& Muliyawati, 2017). Keterampilan mahasiswa dalam memberikan penguatan meningkat sebesar 50 (kriteria sedang), mahasiswa dalam video mengajarnya terlihat menggunakan kata-kata pujian dan mimik serta gerakan tubuh untuk merespons aktivitas siswa.Kegiatan pemberian penguatan dapat dilihat dari cara memberikan penguatan verbal (berupa katakata), penguatan berupa mimik dan gerakan badan, penguatan dengan cara mendekati, penguatan dengan sentuhan, penguatan berupa symbol atau benda, serta penguatan tidak penuh (Irawati, 2020). Dalam penelitian ini terlihat bahwa nilai pretest sebesar 56, sedangkan post tes sebesar 92, dan nilai Gain-nya sebesar 82 (dalam kriteria tinggi). Penggunaan media video dalam proses reinforcement menunjukkan bahwa, praktikan (mahasiswa) mengulang beberapa kali sebelum proses pembuatan video itu diselesaikan, terjadi proses adaptasi, prebaking atau cek and recek secara berulang, sehingga dapat meningkatkan kemampuan untuk memberikan penguatan.

Aspek keterampilan keempat yakni aspek keterampilan bertanya. Keterampilan bertanya merupakan pertanyaan permintaan, retorik, mengarahkan, menggali pertanyaan Taksonomi Bloom, Teknik bertanya sempit, pertanyaan luas, kejelasan dan kaitan pertanyaan, arah pertanyaan menyeluruh, 
menjawab dengan teliti dan tepat (Nurdiansyah et al., 2019; Nurramadhani, 2019). Keterampilan dasar bertanya, dalam penelitian ini menunjukkan bahwa, sebesar 60 dan meningkat menjadi 89, dengan nilai Gainnya, sebesar 73. Kondisi ini menunjukkan, bahwa Keterampilan bertanya, bagi seorang guru merupakan keterampilan yang sangat penting untuk dikuasai (Jaya, 2017). Sebab melalui keterampilan ini guru dapat menciptakan suasana pembelajaran lebih bermakna.Kondisi ini menunjukkan bahwa bertanya dapat dilatih oleh seorang calon guru. Mahasiswa calon guru, berusahamengarahkan peserta didik untuk bertanya, mengaitkan pertanyaan dengan materi, dan memberikan kesempatan siswa untuk berfikir (Habibi \& Firmansyah, 2019). Aspek keterampilan kelima yakni aspek keterampilan menjelaskan. Keterampilan menjelaskan dalam pengajaran adalah penyajian informasi secara lisan yang disorganizer dengan sistematis untuk menunjukkan adanya hubungan antara satu pesan dengan pesan yang lainnya, sehingga tercapai lah suatu pemahaman yang diinginkan (Achdiani \& Rusliyani, 2017; Isradini et al., 2020). Misalnya antara sebab dan akibat, definisi dengan contoh atau dengan suatu yang belum diketahui.Aspek yang dinilai dari keterampilan menjelaskan pelajaran adalah penguasaan bahan materi tanpa melihat buku pelajaran dan menyajikan informasi lisan disampaikan secara sistematis, menjelaskan pesan materi secara terencana (Ambarawati, 2016). Keterampilan menjelaskan materi, dalam penelitian ini sebesar 56, dan meningkat setelah protest sebesar 89 dengan nilai Gainnya sebesar 73 (dengan kriteria tinggi). Dalam perkuliahan secara daring ini, video mahasiswa yang pertama banyak mendapatkan masukan dari mahasiswa lain dan dosen sehingga keterampilan mahasiswa dalam menggunakan media saat posttest sudah jauh lebih baik daripada saat pretest.

Aspek keterampilan keenam yakni aspek keterampilan dasar penggunaan media.Aspek yang dinilai dari keterampilan penggunaan media pembelajaran adalah menyiapkan dan menggunakan media pembelajaran sesuai dengan materi (Rahim et al., 2019; Syahroni, 2020). Keterampilan penggunaan media pembelajaran memperoleh nilai tertinggi pada saat posttest karena pada saat perkuliahan daring, sebagaimana telah dijelaskan di atas, video mahasiswa yang pertama banyak mendapatkan masukan dari mahasiswa lain dan dosen pembina mata kuliah, sehingga pada video mengajar yang kedua mengalami peningkatan. Dalam penelitian ini pada saat pretest nilai keterampilan dasar tentang penggunaan media sebesar 59 , kemudian setelah posttest menjadi 90, dengan nilai Gainnya sebesar 76. Peranan media dan penggunaan media mempengaruhi keberhasilan pembelajaran dan dapat meningkatkan hasil belajar siswa (Nahdi et al., 2020). Aspek keterampilan ketuju yakni keterampilan mengadakan variasi.Keterampilan ini mengadakan variasi merupakan suatu hal yang sangat penting dalam prilaku keterampilan mengajar, yang dimaksid dengan variasi dalam hal ini adalah menggunakan berbagai metode, gaya mengajar misalnya variasi dalam menggunakan sumber bahan pelajaran media pengajaran, variasi dalam bentuk interaksi antara guru dan murid (Koirewoa, 2018). Aspek yang dinilai dari keterampilan mengadakan variasi adalah variasi suara, mimik dan gerak, kesenyapan, kontak pandang, perubahan posisi, memusatkan (tekanan pada butir yang penting), variasi visual (dengan alat pelajaran). Keterampilan ini dari 60 meningkat sebesar 83 saat posttest, dengan gain sebesar 58 (kategori sedang) (kriteria sedang), cara mahasiswa mengadakan variasi dalam pola interaksi dan kegiatan siswa sudah lebih baik (Irawati, 2020). Aspek keterampilan kedelapan yakni keterampilan menutup pelajaran.Aspek yang dinilai dari keterampilan menutup pelajaran adalah meninjau kembali, membuat ringkasan, dan memberikan tindak lanjut berupa saran-saran serta ajakan agar materi yang baru dipelajari.Keterampilan ini meningkat sebesar 54 (kriteria sedang), mahasiswa dalam video mengajarnya telah membuat rangkuman pokok pembelajaran, memberikan contoh aplikasi dari konsep yang telah dipelajari, dan memberikan informasi materi yang akan dipelajari selanjutnya.

Peningkatakan pada tiap-tiap aspek kemampuan mengajar mahasiswa tidak terlepas dari penggunaan model pembelajaran berbasis proyek yang lebih menekankan padakeaktifan siswa dalam melakukan percobaan atau praktek secara langsung. Hasil yang diperoleh dalam penelitian ini sejalan dengan beberapa hasil penelitian terdahulu yang juga mengungkapkan bahwa penerapan model Project Based Learning (PJBL) dalam pembelajaran fisika secara signifikan mampu meningkatkan kemampuan berpikir ktitis peserta didik (Anggreni, 2019). Penelitian lainnya juga mengungkapkan bahwa pembelajaran project based learning berpengaruh besar terhadap kemampuan pemahaman konsep mahasiswa prodi pendidikan matemtika, sehingga model tersebut sangat layak untuk digunakan (Wahyuni, 2019). Penelitian selanjutnya juga menyebutkan bahwa siswa termotivasi melaksanakan kerja proyek yang dilakukan, yang dikerjakan tanpa adanya beban dan membuahkan hasil yang maksimal, serta menjadi penilaian ujian praktik IPA di akhir belajar di sekolah (Handayani, 2020). Sehingga berdasarkan hasil penelitian yang kemudian didukung oleh hasil penelitian terdahulu dapat dikatakan bahwa penerapan model pembelajaran berbasis proyek dapat meningkatkan kemampuan siswa maupun mahasiswa dalam proses pembelajaran daring. 


\section{SIMPULAN DAN SARAN}

Penggunaan model pembelajaran berbasis pryek secara signifikan mampu melatih keterampilan dasar men ajar calon guru kimia, dengan kriteria tinggi.Hal ini dikarenakan pemberian tugas proyek memungkinkan mahasiswa mengembangkan diri secara kreatif dalam pembuatan video pengajaran.

\section{DAFTAR RUJUKAN}

Achdiani, Y., \& Rusliyani, A. (2017). Pengetahuan Keterampilan Dasar Mengajar dalam Menyiapkan Guru Sekolah Menengah Kejuruan. Teknobuga, 5(2), 34-43. https://doi.org/10.1529/jtbb.v5i2.15368.

Aini, H., Suandi, N., \& Nurjaya, G. (2019). Pemberian Penguatan (Reinforcement) Verbal Dan Nonverbal Guru Dalam Pembelajaran Bahasa Indonesia Di Kelas VIII MTSN Seririt. Jurnal Pendidikan Bahasa Dan Sastra Indonesia Undiksha, 8(1). https://doi.org/10.23887/jjpbs.v8i1.20246.

Ambarawati, M. (2016). Analisis Keterampilan Mengajar Calon Guru Pendidikan Matematika Pada MataKuliah Micro Teaching. Pedagogia: Jurnal Pendidikan, 5(1), 81-90. https://doi.org/10.21070/pedagogia.v5i1.91.

Anggreni, Y. dwi. (2019). Meta-Analisis Pengaruh Model Pembelajaran Project Based Learning Terhadap Kemampuan Berpikir Kritis Peserta Didik Sma. Physics Education, 12(4), 881-888. https://doi.org/ $10.24036 / 7912171074$.

Anugrahana, A. (2020). Hambatan, Solusi dan Harapan: Pembelajaran Daring Selama Masa Pandemi Covid19 Oleh Guru Sekolah Dasar. Scholaria: Jurnal Pendidikan Dan Kebudayaan, 10(3), 282-289. https://doi.org/10.24246/j.js.2020.v10.i3.p282-289.

Asmuni, A. (2020). Problematika Pembelajaran Daring di Masa Pandemi Covid-19 dan Solusi Pemecahannya. Jurnal Paedagogy, 7(4), 281-288. https://doi.org/10.33394/jp.v7i4.2941.

Asril, Z. (2017). Micro Teaching disertai dengan Pedoman Pengalaman Lapangan, Jakarta: PT. In Raja Grafindo Persada.

Astini, N. K. suni. (2020). Tantangan Dan Peluang Pemanfaatan Teknologi Informasi Dalam Pembelajaran Online Masa Covid-19. Cetta: Jurnal Ilmu Pendidikan, 3(2), 241-255. https://doi.org/10.37329/cetta.v3i2.452.

Aulia, R., \& Sontani, U. T. (2018). Pengelolaan Kelas Sebagai Determinan Terhadap Hasil Belajar. Jurnal Pendidikan Manajemen Perkantoran, 3(2), 9. https://doi.org/10.17509/jpm.v3i2.11759.

Azrai, E. P., Rini, D. S., \& Suryanda, A. (2020). Micro-teaching in the Digital Industrial Era 4.0: Necessary or not? Universal Journal of Educational Research, 8(4A), 23-30. https://doi.org/10.13189/ujer.2020.081804.

Cahyani, A., Listiana, I. D., \& Larasati, S. P. D. (2020). Motivasi Belajar Siswa SMA pada Pembelajaran Daring di Masa Pandemi Covid-19. Jurnal Pendidikan Islam, 3(01), 123-140. https://doi.org/10.37542/iq.v3i01.57.

Estiastuti, I. A., \& Arini. (2017). Keterampilan Guru Dalam Pengelolahan Kelas Rendah Pada Pembelajaran Tematik di SD. Joyful Learning Journal, 6(2), 1-6. http://journal.unnes.ac.id/sju/index.php/jlj\%0AKETERAMPILAN.

Fahrezi, I., Taufiq, M., Akhwani, A., \& Nafia'ah, N. (2020). Meta-Analisis Pengaruh Model Pembelajaran Project Based Learning Terhadap Hasil Belajar Siswa Pada Mata Pelajaran IPA Sekolah Dasar. Jurnal Ilmiah Pendidikan Profesi Guru, 3(3), 408. https://doi.org/10.23887/jippg.v3i3.28081.

Habibi, A. A., \& Firmansyah, R. A. (2019). Analisis Keterampilan Dasar Mengajar Guru Kimia yang mengkuti MGMP MIPA. Journal of Educational Chemistry (JEC), 1(1), 9-16. https://doi.org/10.21580/jec.2019.1.1.3743.

Handayani, L. (2020). Peningkatan Motivasi Belajar IPA Melalui Model Pembelajaran Project Based Learning pada Masa Pandemi Covid-19 bagi Siswa SMP Negeri 4 Gunungsari. Jurnal Paedagogy, 7(3), 168. https://doi.org/10.33394/jp.v7i3.2726.

Hikmawati, Sahidu, H., \& Kosim. (2020). Tugas Berbasis Proyek untuk Melatih Keterampilan Mengajar Mahasiswa Calon Guru Saat Pandemi Covid-19. Indonesian Journal of Teacher Education, 1(2), 103110. https://journal.publication-center.com/index.php/ijte/article/view/151.

Irawati, H. (2020). Analisis Keterampilan Dasar Mengajar Mahasiswa Calon Guru Biologi Di Pendidikan Biologi FKIP UAD. INKUIRI: Jurnal Pendidikan IPA. https://doi.org/10.20961/inkuiri.v9i1.41378.

Isradini, N., Maula, L. H., \& Sutisnawati, A. (2020). Analisis Peran Guru Sebgai Pengelola Pembelajaran Daring Berbasis Whatsapp Group Di Kelas V Sekolah Dasar. Jurnal Persada, 4(3), 176-181. https://doi.org/10.37150/perseda.v4i2.1237.

Jaya, H. N. (2017). Keterampilan Dasar Guru untuk Menciptakan Suasana Belajar yang Menyenangkan. Pendidikan Dan Ilmu Pengetahuan, 17(1), 23-35. https://doi.org/10.30651/didaktis.v17i1.1555.

Jeklin, A. (2019). Hubungan Keterampilan Bertanya Dan Keterampilan Memberi Penguatan Dengan Hasil 

Belajar
Matematika.
Jurnal
Pendidikan
Dasar,
$7(6)$
1-23.

http://jurnal.fkip.unila.ac.id/index.php/pgsd/article/view/18608/13316.

Karjiyati, V., \& Agustdianita, N. (2017). Pengembangan Model Project Based Learning Dalam Pembelajaran Tematik Menggunakan Pendekatan Saintifik Untuk Mengembangkan Sikap Peduli Lingkungan Dan Kreativitas Bagi Siswa SD. Mimbar PGSD Universitas Pendidikan Ganesha, 10(2), 121-127. https://doi.org/10.33369/pgsd.10.2.121-127.

Koirewoa, D. C. (2018). Kompetensi Pedagogik Mahasiswa Program Pengalaman Lapangan Dalam Pembelajaran Kimia Melalui Scientific Approach. Jurnal Ilmu Pendidikan Indonesia. https://doi.org/10.31957/jipi.v6i1.77.

Ledger, S., \& Fischetti, J. (2020). Micro-teaching 2.0: Technology as the classroom. Australasian Journal of Educational Technology. https://doi.org/10.14742/ajet.4561.

Mansyur, A. R. (2020). Dampak COVID-19 Terhadap Dinamika Pembelajaran Di Indonesia. Education and Learning Journal, 1(2), 113. https://doi.org/10.33096/eljour.v1i2.55.

Mulyaningsih, L., Rufi'i, R., \& Walujo, D. (2021). Project Based Learning dan Contextual Teaching and Learning Serta Gaya Belajar Pada Ilmu Pengetahuan Alam. Edcomtech Jurnal Kajian Teknologi Pendidikan, 6(1), 110-123. https://doi.org/10.17977/um039v6i12021p110.

Nahdi, D. S., Rasyid, A., \& Cahyaningsih, U. (2020). Meningkatkan Kompetensi Profesional Guru Melalui Pengembangan Media Pembelajaran Berbasis Teknologi Informasi. BERNAS: Jurnal Pengabdian Kepada Masyarakat. https://doi.org/10.31949/jb.v1i2.234.

Napsawati. (2020). Analisis Situasi Pembelajaran Ipa Fisika Dengan Metode Daring Di Tengah Wabah Covid19. Jurnal Pendidikan Fisika Dan Terapannya, 3(1). https://doi.org/10.46918/karst.v3i1.546.

Nirmayani, L. H., \& Dewi, N. P. C. P. (2021). Model Pembelajaran Berbasis Proyek (Project Based Learning) Sesuai Pembelajaran Abad 21 Bermuatan Tri Kaya Parisudha. Jurnal Pedagogi Dan Pembelajaran, 4(3), 378. https://doi.org/10.23887/jp2.v4i3.39891.

Nurdiansyah, N., Johar, R., \& Saminan, S. (2019). Keterampilan Bertanya Guru SMP dalam Pembelajaran Matematika. Jurnal Peluang, 7(1). https://doi.org/10.24815/jp.v7i1.13735.

Nurhikmayati, I., \& Sunendar, A. (2020). Pengembangan Project Based Learning Berbasis Kearifan Lokal Berorientasi pada Kemampuan Berpikir Kreatif dan Kemandirian Belajar. Mosharafa: Jurnal Pendidikan Matematika, 9(1), 1-12. https://doi.org/10.31980/mosharafa.v9i1.604.

Nurramadhani, A. (2019). Profil Kualitas Keterampilan Bertanya Mahasiswa Calon Guru Dalam Pembelajaran Sains. Pedagonal: Jurnal Ilmiah Pendidikan, 3(2), 1-9. https://doi.org/10.33751/pedagog.v3i2.1302.

Nurwahidah, I. (2020). Kemampuan Keterampilan Dasar Mengajar Mahasiswa Calon Guru IPA Program Studi Pendidikan IPA. EduTeach: Jurnal Edukasi Dan Teknologi Pembelajaran, 1(2), 22-33. https://doi.org/10.37859/eduteach.v1i2.1957.

Oktawirawan, D. H. (2020). Faktor Pemicu Kecemasan Siswa dalam Melakukan Pembelajaran Daring di Masa Pandemi Covid-19. Jurnal Ilmiah Universitas Batanghari Jambi, 20(2), 541. https://doi.org/10.33087/jiubj.v20i2.932.

Rachmadyanti, P. (2021). Persepsi Mahasiswa PGSD tentang Penggunaan Padlet pada Pembelajaran Microteaching. Jurnal Penelitian Dan Pengembangan Sekolah Dasar, 9(2). https://doi.org/10.22219/jp2sd.v9i2.17105.

Rahim, F. R., Suherman, D. S., \& Murtiani, M. (2019). Analisis Kompetensi Guru dalam Mempersiapkan Media Pembelajaran Berbasis Teknologi Informasi Era Revolusi Industri 4.0. Jurnal Eksakta Pendidikan (JEP), 3(2), 133. https://doi.org/10.24036/jep/vol3-iss2/367.

Rati, N. W., Kusmaryatni, N., \& Rediani, N. (2017). Pengaruh Model Pembelajaran Berbasis Proyek Terhadap Kreativitas Dan Hasil Belajar Pendidikan IPA SD Mahasiswa PGSD Undiksha UPP Singaraja. JPI (Jurnal Pendidikan Indonesia), 6(1). https://doi.org/10.23887/jpi-undiksha.v6i1.9059.

Rezania, V., Nuroh, E. Z., \& Mariyati, L. I. (2020). Kemampuan Cognitive Apprenticeship Sebagai Bagian Dari Keterampilan Dasar Mengajar Guru Sekolah Dasar. Pedagogia : Jurnal Pendidikan, 9(1), 43-52. https://doi.org/10.21070/pedagogia.v9i1.258.

Septyanti, E., \& Kurniawan, O. (2020). Studi Eksploratif Kebutuhan Pembelajaran Daring untuk Mata Kuliah Menyimak pada Masa Pandemi Covid-19. Diglosia: Jurnal Kajian Bahasa, Sastra, Dan Pengajarannya, 3(4), 365-372. https://doi.org/10.30872/diglosia.v3i4.106.

Siahaan, Y. L. O., \& Meilani, R. I. (2019). Sistem Kompensasi dan Kepuasan Kerja Guru Tidak Tetap di Sebuah SMK Swasta di Indonesia. Jurnal Pendidikan Manajemen Perkantoran, 4(2), 141. https://doi.org/10.17509/jpm.v4i2.18008.

Sobron, A. ., Bayu, Rani, \& S, M. (2019). Pengaruh Daring Learning terhadap Hasil Belajar IPA Siswa Sekolah Dasar. Seminar Nasional Sains \& Entrepreneurship, 1(1), 1-5. http://conference.upgris.ac.id/index.php/snse/article/view/204. 
Sufiati, V., \& Afifah, S. N. (2019). Peran perencanaan pembelajaran untuk performance mengajar guru pendidikan anak usia dini. Jurnal Pendidikan Anak, 8(1), 48-53. https://doi.org/10.21831/jpa.v8i1.26609.

Sumar, W. tune. (2020). Pengelolaan Kelas dalam Meningkatkan Motivasi Belajar Siswa. Jambura Journal of Educational Management. https://doi.org/10.37411/jjem.v1i1.105.

Sundari, F. S., \& Muliyawati, Y. (2017). Analisis Keterampilan Dasar Mengajar Mahasiswa PGSD. Pedagonal : Jurnal Ilmiah Pendidikan, 1(1), 26-36. https://doi.org/10.33751/pedagog.v1i1.225.

Sutisnawati, A. (2017). Analisis Keterampilan Dasar Mengajar Mahasiswa Calon Guru Sekolah Dasar. Mimbar Pendidikan Dasar, 8(1), 15-24. https://ejournal.upi.edu/index.php/Mimbardiksar/article/view/7886.

Syahroni, M. (2020). Pelatihan Implementasi Media Pembelajaran Interaktif Guna Peningkatan Mutu Pembelajaran Jarak Jauh. International Journal of Community Service Learning, 4(3). https://doi.org/10.23887/ijcsl.v4i3.28847.

Wahyuni, S. (2019). Pengaruh Model Pembelajaran Project Based Learning Terhadap Kemampuan Pemahaman Konsep Mahasiswa Mata Kuliah Kapita Selekta Matematika Pendidikan Dasar Fkip Umsu. Jurnal EduTech, 5(1), 84-88. https://doi.org/ 10.30596\%2Fedutech.v5i1.2982.

Walilu, R. F., Laim, B. F. N., Mariasa, I. M., Riki, R., \& Alberto, A. (2021). Implementasi Pembelajaran Jarak Jauh Selama Pandemi Covid19 Menggunakan Platform Jitsi Pada Institusi Pendidikan Menggunakan Server Ubuntu.JPB : Jurnal Patria Bahari, 1(1), 1-8. https://doi.org/10.54017/jpb.v1i1.15.

Yuanita, Y. (2019). Tingkat Keterampilan Dasar Mengajar Calon Guru Sekolah Dasar Pada Perkuliahan $\begin{array}{llll}\text { Mikroteaching. } \quad \text { Pedagogia : Jurnal } & \text { 89-84), }\end{array}$ https://doi.org/10.21070/pedagogia.v8i1.1952. 